Journal of Animal and Veterinary Advances $10(7): 865-867,2011$

ISSN: $1680-5593$

(C) Medwell Journals, 2011

\title{
Molecular Investigation on DNA-PKes Gene and Identification of SCID Carriers among Iranian Arabian HorsesUsing a Test Based on PCR
}

\author{
Hamid Reza Seyedabadi, Mohamad Hossein Banabazi, Fazlollah Afraz, \\ Nader Asadzadeh, Arash Javanmard and Ali Javanrouh Aliabad \\ Department of Biotechnology, Animal Science Research Institute of Iran (ASRI), Karaj, I.R. Iran
}

\begin{abstract}
Severe Combined Immunodeficiency Disease (SCID) is an autosomal recessive hereditary disease occurring among Arabian horses. The genetic defect responsible for this disease was recently identified as a 5-basepair deletion in the gene encoding DNA-Protein Kinase catalytic subunit (DNA-PKcs). Horses with one copy of the gene appear normal while horses with two copies of the gene manifest the disease. The only way to avoid the economic losses is early detection of SCID carriers. Because the real value of this test is that breeders can use it to ensure that they will never produce a SCID foal and that they can by breeding carriers to clears, preserve the unique and positive characteristics of exceptional carriers. And thereby breed out the undesirable gene over several generations.
\end{abstract}

Key words: SCID, DNA-PKcs, Iranian arab horse, genetic defect, carrier, preserve

\section{INTRODUCTION}

Severe Combined Immunodeficiency Disease (SCID) has been of grave concern to Arabian horse breeders for the past several decades (McGuire and Poppie, 1973). The first occurrence of SCID in Arabian foals was reported by McGuire and Poppie (1973). The paucity of mature T and $B$ lymphocytes in affected Arabian foals is profound (Magnuson and Perryman, 1986). These foals produce no antibodies after infection or immunization and no evidence of leakiness has been detected SCID foals rarely survive up to 5 months of age before succumbing to infections caused by equine adenovirus, Pneumocystis carinii, Cryptosporidium parvum or many species of bacteria (Lunn et al., 1995). The disease is inherited as an autosomal recessive trait and was suggested that a defect in a single gene is responsible for equine SCID (Thompson et al., 1975; Perryman and Torbeck, 1980). The SCID gene was mapped to chromosome ECA9 (Bailey et al., 1997). Shin et al. (1997) described a 5-basepair deletion in the horse gene encoding DNA-Protein Kinase catalytic subunit (DNA-PKes) is responsible for SCID in Arabian horses.

The mutation prevented translation of the 967 C-terminal amino acids, resulting in a nonstable protein. DNA-PKcs is related to the Phosphatidylinositol 3-Kinase (PI3K) family in which members function in a variety of roles such as signal transduction, control of cell cycle progression and $\mathrm{m}$ aintenance of telomere length
(Finnie et al., 1995). Variable-diversity-joining rearrangement is the mechanism by which gene segments ( $\mathrm{V}, \mathrm{D}$ and $\mathrm{J}$ ) are joined to form the coding sequences of $\mathrm{Ig}$ and TCR variable regions (Weiler et al., 2000). Rearrangement involves two DNA cuts and relegations and is mediated by a lymphoid-specific endonuclease (the RAG 1 and RAG 2 proteins) and ubiquitous components of the DNA Double-strand Break Repair (DSBR) pathway (Shin et al., 1997).

The centrality of $\mathrm{V}$ (D) $\mathrm{J}$ recombination to the development of the immune system is illustrated in situations where the process is impaired (Malynn et al., 1988). At least, four factors are required for both V (D) J recombination and DSBR: the $\mathrm{Ku}$ heterodimer (Ku 86/Ku 70, XRCC5 and XRCC6), DNA-PKcs (XRCC7) and XRCC4 (Taccioli et al., 1994). Defective V (D) J recombination results in a complete block of $\mathrm{B}$ and $\mathrm{T}$ cell lymphopoiesis and the disease severe combined immune deficiency (Shin et al., 1997). Bosma et al. (1983) described a spontaneous mutation in C.B-17 mice resulting in defective $\mathrm{V}$ (D) $\mathrm{J}$ recombination and SCID. In SCID mice, the only step in V (D) J recombination that is impaired is the resolution of coding ends (Peterson et al., 1995).

It was demonstrated that SCID mice also have impairedDNA Double-strand Break Repair (DSBR). Like SCID mice, the immunologic defects in SCID foals can be corrected through transplantation of normal histocompatible bone marrow cells (Shin et al., 1997). This

Corresponding Author: Hamid Reza Seyedabadi, Department of Biotechnology, Animal Science Research Institute of Iran (ASRI), First Dehghan Villa, Shahid Beheshti Ave., P.O. Box 1483-31585, Karaj, Iran 
study intends to molecular investigation on DNA-PKes gene and identification of SCID carriers among Iranian Arabian horses using a test based on PCR.

\section{MATERIALS AND METHODS}

About 120 whole blood samples were randomly collected among Iranian Arabian horses from Khuzestan and Kordan regions in the Southwest and centre of Iran. Genomic DNA was extracted by the salting-out method (Miller et al., 1988) with some modifications. One set of allele-specific primers was designed to amplify only DNA containing the 5-basepair deletion. The primers have the following sequence:

\section{F : 5'-TTC CTG TTG CAA AAG GAG-3' \\ $\mathrm{R}:$ 5'-TTTGTG ATGATG TCA TCC-3'}

Polymerase chain reaction was performed on Biometra PCR system. To produce $259 \mathrm{bp}$ fragment of the DNA-PKcs gene the following PCR mix was composed: 1X PCR buffer; $5 \mathrm{mM}$ Mgc 12;0.25 $\mu \mathrm{M}$ primers; dNTPs $200 \mu \mathrm{M}$; 1 unit of Taq polymerase; Genomic DNA 150 ng/reaction; dd $\mathrm{H}_{2} \mathrm{O}$. The final volume was $15 \mu \mathrm{L}$. Samples were amplified under the following conditions:initial denaturation at $95^{\circ} \mathrm{C}$ for $2.5 \mathrm{~min}$ followed by 36 cycles of $95^{\circ} \mathrm{C}$ for $30 \mathrm{sec}$; annealing $60^{\circ} \mathrm{C}$ for $30 \mathrm{sec}$; extension $72^{\circ} \mathrm{C}$ for $45 \mathrm{sec}$; final extention for $5 \mathrm{~min}$. The products were electrophoresed on $8 \%$ nondenaturing polyacrylamide gels at $80-\mathrm{v}$ at overnight and bands visualized by rapid silver staining (Sanguinetti et al., 1994).

\section{RESULTS AND DISCUSSION}

The results showed total samples were homozygote for $259 \mathrm{bp}$ band (Fig. 1) that is noncarrier. Some studies during 20 years ago indicated that the frequency of affected Arabian foals was around 3\% but carrier frequency is about $28 \%$ and means that one out of every 3 or 4 adult Arabian horses is carrying the gene for this deadly disease (Poppie and McGuire, 1977; Studdert, 1978). Another way of stating is that $7-10 \%$ of all matings are between carriers and thus this proportion of matings is at risk to produce a foal that will soon die from SCID. Probable reasons for these results may be: Preliminary studies of the pedigrees of 21 carriers identified in this study implicate a popular stallion active in late 1920s (Bernoco and Bailey, 1998). The pedigree of this stallion was limited to a single generation in the American Arabian horse registry. It may be there is not any progeny from this stallion within studied samples in

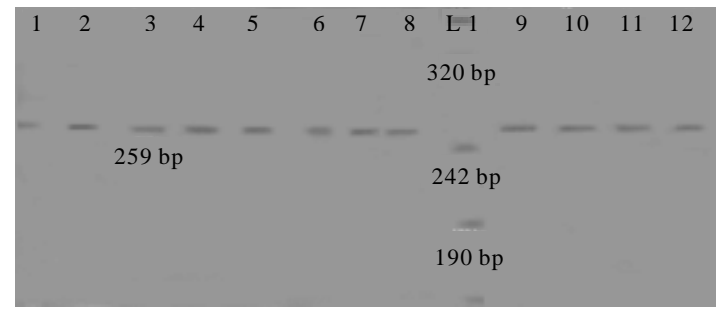

Fig. 1: The genotypes of 12 Iranian Arab horses for DNA-PKcs gene. All samples are homozygote in $259 \mathrm{bp}$ band that is noncarrier. 1-12 lanes and L1 lane are individuals and size marker $\mathrm{V}$ from Roche (Germany), respectively

Iran. The next studies samples were focused on infected flocks and therefore, it is expected high frequency for them. However, the sampling have been randomized. There are two aspects to examine when considering the reduction of SCID. The first is the removal of SCID from the Arab horse population as a whole and the second is the prevention of the conception of affected foals. The ultimate aim for the future would be the complete elimination of the SCID gene from the Arab horse breeding population. This would require the gradual withdrawal of all carrier horses from breeding. If the percentage of carriers in the population turns out to be high, this would take a number of years but would eventually remove the need to test any further, individuals for SCID. Realistically, preventing the breeding of carriers may in fact be undesirable, particularly if highly acclaimed animals prove to be carriers. The SCID defect is only one aspect of a carrier's genetic make-up and the desirable characteristics carried may outweigh this fault. One advantage which the new carrier test provides is that carriers can now be confidently used in breeding programmes with no fear of producing an affected foal. If carriers are only bred with normal horses, there is no possibility of generating a SCID foal. The progeny of all carriers will however, need to be tested to determine whether they are normal or are carriers.

\section{CONCLUSION}

The present study describes a PCR-based test for detection of the gene defect and the results from testing 120 randomly selected Arabian horses. There were not any carrier horse among tested individuals. But the researchers suggest further study on Arab horses throughout of Iran to finding any probable carrier. 


\section{RECOMMENTIONS}

The use of carriers in breeding should therefore carry no stigma but responsible breeders will now ensure that they do not pair a carrier with a carrier. In the long term, the aim for the breed should be to reduce the frequency of carrier-normal matings to lead to the eventual elimination of SCID whilst maintaining desirable genes. It should be pointed out that continued breeding of horses that are carriers of the SCID gene is indeed now possible without the worry of producing SCID foals. For example, carrier stallions that possess highly desirable traits can now be selectively bred to clear (homozygous normal) mares (and vice versa). The resulting foals would have an equal chance of being a carrier or clear of SCID but would definitely not be affected. The foals could be tested anytime after birth to determine their SCID genotype and future matings could be rationally planned. In this study, researchers suggest further study on Arab horses throughout of Iran to finding any probable carrier.

\section{ACKNOWLEDGEMENT}

This research was carried out at Animal Science Research Institution of Iran (Department of Biotechnology). Researchers thank N. Asadi, H. Emrani and $\mathrm{S}$. Dordari for technical assistance.

\section{REFERENCES}

Bailey, E., R.C. Reid, L.C. Skow, K. Mathiason, T.L. Lear and T.C. McGuire, 1997. Linkage of the gene for equine combined immunodeficiency disease to microsatellite markers HTG8 and HTG4; santeny and FISH mapping to ECA9. Anim. Genet., 28: 268-273.

Bernoco, D. and E. Bailey, 1998. Frequency of the SCID gene among Arabian horses in the USA. Anim. Genet., 29: 41-42.

Bosma, G.C., R.P. Custer and M.J. Bosma, 1983. A severe combined immunodeficiency mutation in the mouse. Nature, 301: 527-530.

Finnie, N.J., T.M. Gottlieb, T. Blunt, P.A. Jeggo and S.P. Jackson, 1995. DNA-dependent protein kinase activity is absent in xrs- 6 cells: Implications for sitespecific recombination and DNA double-strand break repair. Proc. Natl. Acad. Sci. USA., 92: 320-324.

Lunn, D.P., J.T. McGuire, C.S. Schobert and M.A. Holmes, 1995. Abnormal patterns of equine leucocyte differentiation antigen expression in severe combined immunodeficiency foals suggests the phenotype of normal equine natural killer cells. Immunology, 84: $495-499$.
Magnuson, N.S and L.E. Perryman, 1986. Metabolic defects in severe combined immunodeficiency in man and animals. Comparative Biochem. Physiol. Part B: Comparative Biochem., 83: 701-710.

Malynn, B.A., T.K. Blackwell, G.M. Fulop, G.A. Rathbun and A.J. Furley et al., 1988. The scid defect affects the final step of the immunoglobulin VDJ recombinase mechanism. Cell, 54: 453-460.

McGuire, T.C. and M.J. Poppie, 1973. Hypogammaglobulinemia and thymic hypoplasia in horses: A primary combined imunodeficiency disorder. Infect Immun., 8: 272-277.

Miller, S.A., D.D. Dykes and H.F. Polesky, 1988. A simple salting out procedure for extracting DNA from human nucleated cells. Nucleic Acids Res., 16: 1215-1215.

Perryman, L.E. and R.L. Torbeck, 1980. Combined immunodeficiency of Arabian horses: Confirmation of autosomal recessive mode of inheritance. J. Am. Vet. Med. Assoc., 176: 1250-1251.

Peterson, S.R., A. Kurimasa, M. Oshimura, W.S. Dynan, E.M. Bradbury and D.J. Chen, 1995. Loss of the catalytic subunit of the DNA-dependent protein kinase in DNA double-strand-break-repair mutant mammalian cells. Proc. Natl. Acad. Sci. USA., 92: 3171-3174.

Poppie, M.J. and T.C. McGuire, 1977. Combined immunodeficiency in foals in Arabian breeding: Evalution of mode of inheritance and estimation of prevalence of affected foals and carrier mares and stallions. J. Am. Vet. Med. Assoc., 170: 31-33.

Sanguinetti, C.J., E.D. Neto and A.J.G. Simpson, 1994. Rapid silver staining and recovery of PCR product separated on polyacrylamide gels. Biotechniques, 17: 914-921.

Shin, E.K., L.E. Perryman and K. Meek, 1997. A kinasenegative mutation of DNA-PK $(\mathrm{CS})$ in equine SCID results in defective coding and signal joint formation. J. Immunol., 158: 3565-3569.

Studdert, M.J., 1978. Primary, severe, combined immunodeficiency disease of Arabian foals. Aust. Vet. J., 54: 411-417.

Taccioli, G.E. T.M. Gottlieb, T. Blunt, A. Priestley and J. Demengeot et al., 1994. Ku80: Product of the XRCC5 gene and its role in DNA repair and $\mathrm{V}(\mathrm{D}) \mathrm{J}$ recombination. Science, 265: 1442-1445.

Thompson, D.B, J.M. Studdert, R.G. Beilharz and I.R. Littlejohns, 1975. Inheritance of a lethal immunodeficiency disease of Arabian foals. Aust. Vet. J., 51: 109-113.

Weiler, R., R. Leber, B.B. Moore, L.F. van Dyk, L.E. Perryman and K. Meek, 2000. Equine severe combined immunodeficiency: A defect in $\mathrm{V}(\mathrm{D}) \mathrm{J}$ recombination and DNA-dependent protein kinase activity. Proc. Natl. Acad. Sci. USA., 92: 1148-2249. 